\title{
Biodiversity of the Gammaridea and Corophiidea (Crustacea: Amphipoda) from the Beagle Channel and the Straits of Magellan: a preliminary comparison between their faunas
}

\author{
Ignacio L. Chiesa ${ }^{1,2}$ \& Gloria M. Alonso ${ }^{2}$ \\ 1 Laboratorio de Artrópodos, Departamento de Biodiversidad y Biología Experimental, Facultad de Ciencias Exactas \\ y Naturales, Universidad de Buenos Aires, Ciudad Universitaria, C1428EHA, Buenos Aires, Argentina; ichiesa@ \\ bg.fcen.uba.ar \\ 2 Museo Argentino de Ciencias Naturales “Bernardino Rivadavia”, Div. Invertebrados, Av. Ángel Gallardo 470, \\ C1405DJR, Buenos Aires, Argentina; galonso@macn.gov.ar
}

Received 10-XI-2005. C Corrected 25-IV-2006. ～Accepted 16-III-2007.

\begin{abstract}
Gammaridea and Corophiidea amphipod species from the Beagle Channel and the Straits of Magellan were listed for the first time; their faunas were compared on the basis of bibliographic information and material collected in one locality at Beagle Channel (Isla Becasses). The species Schraderia serraticauda and Heterophoxus trichosus (collected at Isla Becasses) were cited for the first time for the Magellan region; Schraderia is the first generic record for this region. A total of 127 species were reported for the Beagle Channel and the Straits of Magellan. Sixty-two species were shared between both passages ( $71.3 \%$ similarity). The amphipod species represented 34 families and 83 genera. The similarity at genus level was $86.4 \%$, whereas 23 of the 34 families were present in both areas. For all species, 86 had bathymetric ranges above $100 \mathrm{~m}$ and only 12 species ranged below $200 \mathrm{~m}$ depth. In the Beagle Channel, only one species had a depth record greater than $150 \mathrm{~m}$, whereas in the Straits of Magellan, 15 had such a record. The Beagle Channel and the Straits of Magellan contain $57.5 \%$ of the species, $71 \%$ of the genera and $77.3 \%$ of the families of Gammaridea and Corophiidea from the entire Magellan region. Rev. Biol. Trop. 55 (Suppl. 1): 103-112. Epub 2007 June, 29.
\end{abstract}

Key words: amphipods, biodiversity, Beagle Channel, Straits of Magellan, Magellan region.

The Beagle Channel and the Straits of Magellan are two passages located in the southern tip of South America, connecting the Atlantic and Pacific Oceans (Fig. 1). Both the channel and the straits, including fjords, inner channels and inlets, are characterized by a complex coastline and different depths along their extensions (Hamamé and Antezana 1999, Pagès and Orejas 1999).

The Beagle Channel extends about 300 $\mathrm{km}$; the eastern section has about $50 \mathrm{~m}$ depth and the western end $650 \mathrm{~m}$ (Colizza 1991); the bottoms of the channel are basically muddysandy, although in some sections predominate rocks, crushed shells and coarse sand (Brambati et al. 1991, Colizza 1991); the salinity reaches values not higher than 32 psu, or varies between 27 and 31 psu (Iturraspe et al. 1989); the surface temperature ranges between $3-10{ }^{\circ} \mathrm{C}$ according to the season of the year (Iturraspe et al. 1989). The Straits of Magellan has an extension of $570 \mathrm{~km}$ and its depth increases from the east to the west, reaching in the western section $1100 \mathrm{~m}$; in the eastern side bottoms are mainly sandy, in the middle section these are pelitic and in the west side predominates muddy bottoms; the salinity varies between 28 and 32.5 psu; the surface temperature averages $7.3{ }^{\circ} \mathrm{C}$ (Brambati et al. 1991, Panella et al. 1991).

The Beagle Channel and the Straits of Magellan are areas of great biogeographic and 
ecological importance due to their intermediate position between the Atlantic and Pacific Oceans, their proximity to the Antarctic and the influence of the sub-Antarctic currents (Knox 1994, Brandt et al. 1997, Gambi and Mariani 1999, Ríos et al. 2003).

From the biogeographic point of view, both passages are included in the Magellan region (Bastida et al. 1992, Lancellotti and Vásquez 2000). De Broyer and Rauschert (1999) listed a total of 206 amphipod species for this region, and recently, Chiesa et al. (2005) increased the number of species to 219 .

The study of the Gammaridea and Corophiidea amphipods (Crustacea:Amphipoda) from the Beagle Channel and the Straits of Magellan was initiated mainly by Stebbing (1888) and Schellenberg (1931) on the basis of material collected by the RV Challenger and the Swedish Antarctic Expedition, respectively.

The aims of this contribution are to ascertain the biodiversity of the Beagle Channel and the Straits of Magellan, the bathymetric ranges of the species and the faunistic affinity between the channel and the straits.

\section{MATERIALS AND METHODS}

Part of the information on the species richness of Gammaridea and Corophiidea was obtained through specimens (a total of 2 977) collected at five localities along the Beagle Channel (Bahía Ushuaia, Isla Gable, Punta Moat, Cabo San Pío and Bahía Slogett) identified by Chiesa et al. (2005), and material from Isla Becasses (402 specimens), also located in the Beagle Channel (54 $57^{\prime}$ 'S $67^{\circ} 01^{\prime} \mathrm{W}$; 30-40 $\mathrm{m}$ depth), analysed afterwards and here reported for the first time.

Other records from the Beagle Channel and those from the Straits of Magellan came from a personal compilation of previous literature, based on the following publications: Stebbing (1888), Schellenberg (1931), and De Broyer and Rauschert (1999). The catalogues by Lowry and Bullock (1976), Gonzalez (1991) and De Broyer and Jażdżewski (1993) -based on prior published data- were also reviewed for this contribution. Moreover, most of the original descriptions were consulted. The bathymetric ranges (minimum and maximum depths) of the species taken into account were detailed when possible.

Isla Picton, Isla Nueva, and Isla Lennox were considered as part of the Beagle Channel, and Cabo Vírgenes and Punta Dungeness as belonging to the Straits of Magellan (Fig. 1); the records from these areas were also based on the literature mentioned above.

The taxonomic classification of Gammaridea and Corophiidea follows Barnard and Karaman (1991) and Myers and Lowry (2003), respectively; the families Caprellidae and Cyamidae were not considered herein. The faunistic affinity between the Beagle Channel and the Straits of Magellan was estimated using Simpson's Coefficient of Similarity: $\mathrm{C} / \mathrm{N} \times 100$, where $\mathrm{C}=$ number of shared species and $\mathrm{N}=$ total number of species reported from the smaller of the two groups being compared (Cheetham and Hazel 1969).

\section{RESULTS}

A total of 127 species of Gammaridea and Corophiidea were recognized in the Beagle Channel and the Straits of Magellan (Table 1). From these, 102 species were present in the Straits of Magellan and 87 in the Beagle Channel. Both areas shared 62 species, which represented $71.3 \%$ of similarity.

The 127 amphipod species recorded from both areas were comprised by 34 families and 83 genera. A total of 25 families were reported for the Beagle Channel, whereas 32 families occurred in the Straits of Magellan. Twenty three families co-occurred in both passages. The families Ampeliscidae, Colomastigidae, Epimeriidae, Gammaridae s.l., Phoxocephalopsidae, Platyischnopidae, Podoceridae, Urohaustoriidae and Zobrachoidae were present in the Straits of Magellan but not in the Beagle Channel, whereas Cyproideidae and Eophliantidae were found only in the Beagle Channel (Table 1). 


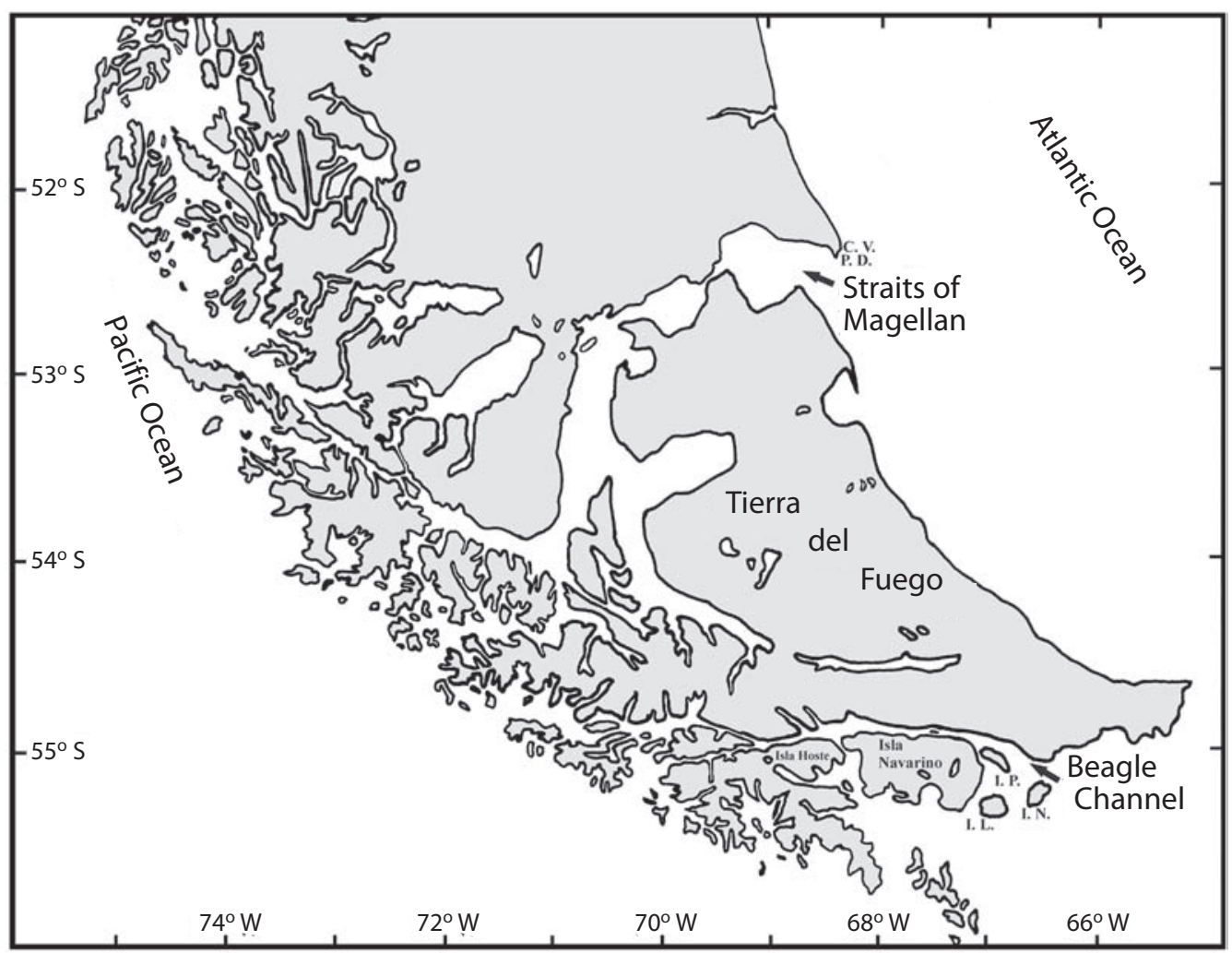

Fig. 1. Straits of Magellan and the Beagle Channel. Cabo Vírgenes (CV); Punta Dungeness (PD); Isla Picton (IP); Isla Nueva (IN); Isla Lennox (IL)

Lysianassidae s.l., Phoxocephalidae, Eusiridae s.l. and Gammarellidae were the families with the highest number of species in both the Straits of Magellan (18, 9, 8 and 8 species, respectively) and the Beagle Channel (12, 8, 10 and 10 species, respectively).

In the Straits of Magellan, 75 genera were found, 24 of them were not present in the Beagle Channel. A total of 59 genera have been reported from the Beagle Channel, from which eight have not been recorded for the Straits of Magellan (Table 1). The Magellan Strait and the Beagle Channel shared 51 genera, representing $86.4 \%$ of similarity.

With respect to the bathymetric range of the listed species, there was no documented depth data for 20 species present in either area or both together. For the Beagle Channel and the Straits of Magellan a total of 86 species were found in ranges shallower than 100 $\mathrm{m}$ depth. From these, 55 species had ranges from low tide down to $50 \mathrm{~m}$ depth, among which seven were recorded exclusively at low tide. Twelve species inhabited a depth range that exceeded $200 \mathrm{~m}$, and only one of them (Victorhensenoides arntzi) was present in the Beagle Channel (Table 1).

From the total of species recorded for the Straits of Magellan, 26 had records exclusively between 0 and $50 \mathrm{~m}$ depth, and 30 species were found in depths below $80 \mathrm{~m}$. In the Beagle Channel, 61 species were present exclusively in a range between 0 and $50 \mathrm{~m}$ depth, and 16 species were found in depths below $80 \mathrm{~m}$. Only one species was reported from depths deeper than $150 \mathrm{~m}$ in the Beagle Channel, whereas in the Straits of Magellan 15 species were found below $150 \mathrm{~m}$.

From Isla Becasses, 19 species of Gammaridea and Corophiidea amphipods were 
TABLE 1

List of gammaridean and corophiidean amphipods present in the Straits of Magellan (SM) and the Beagle Channel (BC), including their local bathymetric ranges

SM Depth (m) BC Depth (m)

AMPELISCIDAE

Ampelisca composita Schellenberg, 1931

Ampelisca dentifera Schellenberg, 1931

$\begin{array}{cc}X & ? \\ X & 58 \\ X & 54\end{array}$

Ampelisca gracilicauda Schellenberg, 1931

$\mathrm{X} \quad 54$

AMPHILOCHIDAE

Amphilochus marionis Stebbing, 1888

Gitanopsis squamosa (Thomson, 1880)

$\mathrm{X} ?$

AMPITHOIDAE

Peramphithoe femorata (Kroyer, 1845)

$\mathrm{X}$

X $15-100$

AORIDAE

Aora anomala Schellenberg, 1926

B Lembos argentinensis Alonso, 1992

Lembos? fuegiensis (Dana, 1853)

$\mathrm{X}$

$11-27$

$\mathrm{X}$

LT

\section{COLOMASTIGIDAE}

Colomastix fissilingua Schellenberg, 1926

\section{COROPHIIDAE}

Crassicorophium bonellii Milne-Edwards, 1830

Haplocheira balssi Schellenberg, 1931

B Haplocheira barbimana robusta K. H. Barnard, 1932

CYPROIDEIDAE

Victorhensenoides arntzi Rauschert, 1997

DEXAMINIDAE

Atylus dentatus (Schellenberg, 1931)

Atylus villosus Bate, 1862

Paradexamine nana Stebbing, 1914

Polycheria acanthocephala Schellenberg, 1931

Polycheria similis Schellenberg, 1931

EOPHLIANTIDAE

Bircenna fulva Chilton, 1884

EPIMERIIDAE

Metepimeria acanthura Schellenberg, 1931

EUSIRIDAE s.l.

B Atyloella dentata K. H. Barnard, 1932

B Atyloella magellanica (Stebbing, 1888)

Eusiroides monoculoides (Haswell, 1879)

B Eusirus antarcticus Thomson, 1880

Paramoera brachyura Schellenberg, 1931

Paramoera fissicauda (Dana, 1852)

Paramoera parva Ruffo, 1949

Paramoera pfefferi Schellenberg, 1931

Rhachotropis schellenbergi Andres, 1982
$\mathrm{X}$

$\mathrm{X}$

$\mathrm{X}$

$\mathrm{X}$
X 90

$\begin{array}{cccc}\text { X } & 11-18 & \text { X } & 4-27 \\ & & \text { X } & 5-40 \\ \text { X } & 11-270 & \text { X } & 2-4\end{array}$

$\mathrm{X}$

X 21-23

X $18-36$

X 90

$\mathrm{X} \quad 18-36$

$\mathrm{X}$ ?

X 100

X $15-25$

$\mathrm{X}$ 27-90

$\begin{array}{cccc} & & \mathrm{X} & 15-40 \\ \mathrm{X} & 11-270 & \mathrm{X} & 5-100 \\ \mathrm{X} & 36-54 & \mathrm{X} & 5-30 \\ \mathrm{X} & 11-270 & \mathrm{X} & 15-100 \\ \mathrm{X} & ? & \mathrm{X} & \text { LT } \\ \mathrm{X} & \text { LT } & \mathrm{X} & \text { LT-27 } \\ & & \mathrm{X} & ? \\ \mathrm{X} & \text { LT-18 } & \mathrm{X} & 2-30 \\ \mathrm{X} & 27 & & \end{array}$


List of gammaridean and corophiidean amphipods present in the Straits of Magellan (SM) and the Beagle Channel (BC), including their local bathymetric ranges

B Schraderia serraticauda (Stebbing, 1888)

Tylosapis dentatus (Stebbing, 1888)

\section{EXOEDICEROTIDAE}

Bathyporeiapus magellanicus Schellenberg, 1931

Exoediceropsis chiltoni Schellenberg, 1931

Metoediceros fuegiensis Schellenberg, 1931

GAMMARELLIDAE

Austroregia batei (Cunningham, 1871)

Austroregia huxleyana (Bate, 1862)

Austroregia regis (Stebbing, 1914)

Chosroes incisus Stebbing, 1888

Gondogeneia antarctica (Chevreux, 1906)

Gondogeneia gracilicauda (Schellenberg, 1931)

Gondogeneia macrodon (Schellenberg, 1931)

Gondogeneia patagonica Alonso, 1986

Gondogeneia simplex (Dana, 1852)

Gondogeneia thurstoni Alonso, 1989

Gondogeneia ushuaiae (Schellenberg, 1931)

GAMMARIDAE s.l.

Maera eugeniae Schellenberg, 1931

HYALIDAE

Apohyale hirtipalma (Dana, 1852)

IPHIMEDIIDAE

B Iphimedia magellanica Watling \& Holman, 1980

B Iphimedia multidentata (Schellenberg, 1931)

Pariphimedia normani (Cunningham, 1871)

Pseudiphimediella glabra (Schellenberg, 1931)

Pseudiphimediella nodosa (Dana, 1852)

ISCHYROCERIDAE

Ischyrocerus sp. $\mathrm{n}$.

Jassa alonsoae Conlan, 1990

Jassa justi Conlan, 1990

Pseudischyrocerus denticauda Schellenberg, 1931

Ventojassa georgiana (Schellenberg, 1931)

LEUCOTHOIDAE

Leucothoe spinicarpa (Abildgaard, 1789)

\section{LILJEBORGIIDAE}

Liljeborgia longicornis (Schellenberg, 1931)

B Liljeborgia macrodon Schellenberg, 1931

B Liljeborgia octodentata Schellenberg, 1931

$\begin{array}{lll} & \text { X } & 30-40 \\ X \quad 99-270 & X & 4-100\end{array}$

$\mathrm{X}$
$\mathrm{X}$

$\mathrm{X} ?$

$\mathrm{X}$ ?

X $11-90$

X 18-54

$\mathrm{X} \quad$ ?

$\mathrm{X}$ ?

$5-54$

$\mathrm{X}$ ?

X $15-54$

X 15-25

$\mathrm{X} \quad$ ? $\quad \mathrm{X} \quad$ LT-14

X $15-27$

X $\quad$ LT-180 $\quad X \quad$ LT

$X \quad$ LT-27

$\mathrm{X}$

?

X $\quad 58$

X LT

X

LT

$\begin{array}{cccc} & & \text { X } & 15-40 \\ X & 27 & \text { X } & 5-40 \\ X & 11-18 & \text { X } & 15-27 \\ X & 18-270 & \text { X } & 5-30 \\ X & 11-54 & \text { X } & 15-35\end{array}$

$\begin{array}{cccc} & & \mathrm{X} & 15-27 \\ & & \mathrm{X} & ? \\ & & \mathrm{X} & 3-14 \\ \mathrm{X} & 180 & \mathrm{X} & 5 \\ \mathrm{X} & ? & \mathrm{X} & 15-27 \\ & & & \\ \mathrm{X} & 18-270 & \mathrm{X} & 18-125 \\ & & & \\ \mathrm{X} & ? & & \\ \mathrm{X} & 11-54 & \mathrm{X} & 5-40 \\ \mathrm{X} & 11-180 & \mathrm{X} & 5-40\end{array}$

LYSIANASSIDAE s.l. 
List of gammaridean and corophiidean amphipods present in the Straits of Magellan (SM) and the Beagle Channel (BC), including their local bathymetric ranges

Acontiostoma marionis Stebbing, 1888

Aristias antarcticus Walker, 1906

B Erikus dahli Lowry \& Stoddart, 1987

Eurythenes gryllus (Lichtenstein, 1822)

Lysianopsis subantarctica (Schellenberg, 1931)

Orchomenella (Orchomenopsis) cavimana (Stebbing, 1888)

Orchomenella (Orchomenopsis) chilensis (Heller, 1865)

Pachychelium schellenbergi Lowry, 1984

Parawaldeckia kidderi (Smith, 1876)

Socarnoides unidentatus (Schellenberg, 1931)

Stenia magellanica Dana, 1852

Stephensenia haematopus Schellenberg, 1928

Stomacontion pepinii (Stebbing, 1888)

Tryphosella? paramoi (Schellenberg, 1931)

Tryphosella? serrata (Schellenberg, 1931)

Tryphosella schellenbergi (Schellenberg, 1931)

B Tryphosites chevreuxi Stebbing, 1914

Tryphosoides falcatus Schellenberg, 1931

Uristes serratus Schellenberg, 1931

Uristes subchelatus (Schellenberg, 1931)

Uristes sp. $\mathrm{n}$.

OCHLESIDAE

B Curidia magellanica Coleman \& J. L. Barnard, 1991

OEDICEROTIDAE

Monoculopsis vallentini Stebbing, 1914

Oediceroides lahillei lahillei Chevreux, 1911

PHOTIDAE

B Gammaropsis (Gammaropsis) deseadensis Alonso, 1981

Gammaropsis (Gammaropsis) longicornis Walker, 1906

Gammaropsis (Gammaropsis) longitarsus (Schellenberg, 1931)

Gammaropsis (Gammaropsis) monodi (Schellenberg, 1931)

Gammaropsis (Gammaropsis) triodon (Schellenberg , 1926)

B Gammaropsis (Paranaenia) dentifera (Haswell, 1879)

Photis (Photis) sp. n.

PHOXOCEPHALIDAE

Fuegiphoxus abjectus J. L Barnard \& C. M. Barnard, 1980

Fuegiphoxus fuegiensis (Schellenberg, 1931)

B Heterophoxus trichosus K. H. Barnard, 1932

Heterophoxus videns K. H. Barnard, 1930

Metharpinia longirostris Schellenberg, 1931

Microphoxus cornutus (Schellenberg, 1931)

Parafoxiphalus longicarpus Alonso de Pina, 2001

\begin{tabular}{|c|c|c|c|}
\hline $\mathrm{X}$ & ? & & \\
\hline \multirow[t]{2}{*}{$\mathrm{X}$} & 270 & $\mathrm{X}$ & $125-140$ \\
\hline & & $\mathrm{X}$ & $5-40$ \\
\hline $\mathrm{X}$ & ? & & \\
\hline \multirow[t]{2}{*}{$\mathrm{X}$} & $27-90$ & $\mathrm{X}$ & $11-27$ \\
\hline & & $\mathrm{X}$ & 60-115 \\
\hline $\mathrm{X}$ & $11-36$ & $\mathrm{X}$ & 10-115 \\
\hline $\mathrm{X}$ & ? & $\mathrm{X}$ & $1-18$ \\
\hline $\mathrm{X}$ & $\mathrm{LT}$ & $\mathrm{X}$ & $2-22$ \\
\hline $\mathrm{X}$ & ? & & \\
\hline $\mathrm{X}$ & $2-3$ & & \\
\hline $\mathrm{X}$ & ? & & \\
\hline $\mathrm{X}$ & $5-90$ & $\mathrm{X}$ & $30-35$ \\
\hline $\mathrm{X}$ & ? & & \\
\hline $\mathrm{X}$ & 27-55 & $\mathrm{X}$ & $18-55$ \\
\hline $\mathrm{X}$ & $4-54$ & $\mathrm{X}$ & LT-115 \\
\hline $\mathrm{X}$ & $4-270$ & $\mathrm{X}$ & $2-115$ \\
\hline $\mathrm{X}$ & ? & & \\
\hline $\mathrm{X}$ & $11-18$ & & \\
\hline \multirow[t]{2}{*}{$\mathrm{X}$} & $18-54$ & & \\
\hline & & $\mathrm{X}$ & $5-17$ \\
\hline $\mathrm{X}$ & $92-101$ & $\mathrm{X}$ & $30-40$ \\
\hline $\mathrm{X}$ & LT-4 & $\mathrm{X}$ & $5-9$ \\
\hline \multirow[t]{2}{*}{$\mathrm{X}$} & ? & $\mathrm{X}$ & 35 \\
\hline & & $\mathrm{X}$ & $15-40$ \\
\hline \multirow[t]{2}{*}{$\mathrm{X}$} & ? & & \\
\hline & & $\mathrm{X}$ & $7-100$ \\
\hline $\mathrm{X}$ & ? & $\mathrm{X}$ & $\mathrm{LT}$ \\
\hline $\mathrm{X}$ & ? & & \\
\hline \multirow[t]{2}{*}{$\mathrm{X}$} & 36 & $\mathrm{X}$ & $5-100$ \\
\hline & & $\mathrm{X}$ & $15-25$ \\
\hline $\mathrm{X}$ & $36-55$ & & \\
\hline \multirow[t]{2}{*}{$\mathrm{X}$} & $0-90$ & $\mathrm{X}$ & LT-35 \\
\hline & & $\mathrm{X}$ & $30-40$ \\
\hline $\mathrm{X}$ & $5-14$ & $\mathrm{X}$ & $5-45$ \\
\hline $\mathrm{X}$ & ? & & \\
\hline \multirow[t]{2}{*}{$\mathrm{X}$} & $4-14$ & $\mathrm{X}$ & LT-30 \\
\hline & & $\mathrm{X}$ & $5-30$ \\
\hline
\end{tabular}


List of gammaridean and corophiidean amphipods present in the Straits of Magellan (SM) and the Beagle Channel (BC), including their local bathymetric ranges

B Phoxorgia sinuata (K. H. Barnard, 1932)

Proharpinia antipoda Schellenberg, 1931

Proharpinia stephenseni (Schellenberg, 1931)

Pseudharpinia dentata Schellenberg, 1931

PHOXOCEPHALOPSIDAE

Phoxocephalopsis gallardoi J. L. Barnard \& Clark, 1984

Phoxocephalopsis zimmeri Schellenberg, 1931

PLATYISCHNOPIDAE

Eudevenopus gracilipes (Schellenberg, 1931)

PODOCERIDAE

Podocerus cristatus rotundatus Schellenberg, 1931

SEBIDAE

Seba saundersii Stebbing, 1875

Seba subantarctica Schellenberg, 1931

Seba typica (Chilton, 1884)

STEGOCEPHALIDAE

Andaniotes linearis K. H. Barnard, 1932

\section{STENOTHOIDAE}

Metopoides magellanicus (Stebbing, 1888)

B Probolisca elliptica (Schellenberg, 1931)

B Probolisca nasutigenes (Stebbing,1888)

Probolisca ovata (Stebbing, 1888)

Torometopa compacta (Stebbing, 1888)

Torometopa crenatipalmata (Stebbing, 1888)

Toremetopa parallelocheir (Stebbing, 1888)

TALITRIDAE

Orchestia scutigerula Dana, 1852

Protorchestia nitida (Dana, 1852)

Transorchestia chiliensis (Milne-Edwards, 1840)

UROHAUSTORIIDAE

Huarpe escofeti J. L. Barnard \& Clark, 1982

UROTHOIDAE

Urothoe falcata Schellenberg, 1931

\section{ZOBRACHOIDAE}

Chono angustiarum Clark \& J. L. Barnard, 1987

Tonocote introflexidus Clark \& J. L. Barnard, 1988

Tonocote magellani Clark \& J. L. Barnard, 1986

$\begin{array}{cccc}X & 13-54 & X & 5-54 \\ X & 18-270 & X & 5-45 \\ X & ? & X & 4-30 \\ X & ? & & \end{array}$

$\mathrm{X}$

X 4

$\mathrm{X}$

$\mathrm{X}$

180

X 99

X 5-30

$\mathrm{X}$

X 5-100

$\mathrm{X} \quad 15-27$

$\mathrm{X}$

90-270

$\mathrm{X}$

100

$\mathrm{X}$

99

$\begin{array}{cccc} & & \mathrm{X} & 15-100 \\ & & \mathrm{X} & 15-40 \\ \mathrm{X} & 99 & \mathrm{X} & 4-35 \\ \mathrm{X} & 99-270 & & \\ \mathrm{X} & 99 & & \\ \mathrm{X} & 99 & & \end{array}$

$\begin{array}{llll}\text { X } & \text { LT } & \text { X } & \text { LT } \\ \text { X } & \text { LT } & \text { X } & \text { LT } \\ \text { X } & \text { LT } & \text { X } & \text { LT }\end{array}$

$\mathrm{X}$

$11-12$

$\mathrm{X}$

?

$\mathrm{X}$

15-35

?: without documented depth data; LT: low tide. Species collected in Isla Becasses (B) 
identified; from these, Curidia magellanica is a new record for the Beagle Channel, and two species (Schraderia serraticauda and Heterophoxus trichosus) are cited for the first time for the Magellan region (Table 1).

\section{DISCUSSION}

The knowledge of the amphipod fauna from both passages is dispersed in several taxonomic papers (Schellenberg 1931, Lowry and Bullock 1976, Gonzalez 1991, De Broyer and Jażdżewski 1993 and De Broyer and Rauschert 1999). The present contribution provides the first comprehensive list of the gammaridean and corophiidean amphipod species from the Beagle Channel and the Straits of Magellan, and the first preliminary comparison between their faunas.

The study of the material from Isla Becasses in the Beagle Channel yielded two new records of species for the entire Magellan region, Schraderia serraticauda and Heterophosus trichosus; these records increase the number of species from 219 (Chiesa et al. 2005) to 221 in the Magellan region. S. serraticauda was previously known from the sub-Antarctic islands (Auckland and Macquarie islands) and $H$. trichosus from the West Antarctic (Bransfield Strait and South Shetland islands); moreover, Schraderia represents the first record of the genus for the Magellan region.

The species reported as Uristes serratus (Schellenberg, 1931) for the Argentine sector of the Beagle Channel (Bahia Ushuaia) by Chiesa et al. (2005) is a new undescribed species. This is the first record of Uristes for the Beagle Channel.

All the amphipod families lacking in the Straits of Magellan and the Beagle Channel, but present in the rest of the Magellan region, were characterized by their low diversity in this region, since they only comprised one or two species (De Broyer and Rauschert 1999). On the contrary, Lysianassidae s.l., one of the most specious families in the entire Magellan region (De Broyer and Rauschert 1999), was also well represented in the areas analysed by us. The absence of Ampeliscidae in the Beagle Channel is relative, since Chiesa et al. (2005) found one species (afterwards it was concluded that they could be two) in a locality in the vicinity of the Beagle Channel (Bahía Aguirre).

The genera Ampelisca (Ampeliscidae), Polycheria (Dexaminidae), Torometopa (Stenothoidae) and Tonocote (Zobrachoidae) with more than one species, have been reported only for the Straits of Magellan.

The higher number of species reported only from shallow waters of the Beagle Channel and the Straits of Magellan and the low number found in deeper waters indicate the necessity of collecting material at depths below $100 \mathrm{~m}$ in both passages, especially in the Beagle Channel, where only one species (Victorhensenoides arntzi) was found at a depth about $150 \mathrm{~m}$. In general, more extensive sampling in the channel and the straits would allow a more accurate estimation of the bathymetric ranges of the species.

Although the Magellan region amphipod fauna of Gammaridea and Corophiidea is far from being well known, it is remarkable that $57.5 \%$ of the species, $71 \%$ of the genera and $77.3 \%$ of the families from the Magellan region (De Broyer and Rauschert 1999, Chiesa et al. 2005) are present in both the Beagle Channel and the Straits of Magellan. These comparatively high percentages, estimated for the southern tip of South America, could be due to the fact that this area has been more intensively sampled than the northern part of the Magellan region (Atlantic and Pacific Oceans).

It is expected that the results on species richness and faunistic affinities obtained here will be modified as new samples from the Beagle Channel and the Straits of Magellan are studied; the existence of several still undescribed taxa (new genera and species) and new records listed by De Broyer and Rauschert (1999) for the Beagle Channel, the Straits of Magellan and adjacent magellanic waters, also support this hypothesis. 


\section{ACKNOWLEDGMENTS}

We thank the staff of the Base Naval Ushuaia for their logistic support; Gustavo Lovrich for his kind help with the survey arrangements and Diego Zelaya for his comments on the manuscript. This study was partially supported by the Agencia Nacional de Promoción Científica y Tecnológica (PICT No. 11.180).

\section{RESUMEN}

Se confeccionó el primer listado de anfípodos Gammaridea y Corophiidea del Canal Beagle y del Estrecho de Magallanes, y se compararon, en forma preliminar, sus faunas con base en información bibliográfica y material recolectado en una localidad del Canal Beagle (Isla Becasses). Las especies Heterophoxus trichosus y Schraderia serraticauda (recolectadas en Isla Becasses) son citadas por primera vez para la región magallánica; Schraderia representa el primer registro genérico para dicha región. Un total de 127 especies fueron registradas para el Canal Beagle y el Estrecho de Magallanes, compartiendo entre ambos 62 especies, lo que representa una similitud del $71.3 \%$. El total de las especies pertenece a 34 familias y 83 géneros. La similitud a nivel genérico fue del $86.4 \%$, mientras que 23 familias estuvieron presentes en ambos pasajes. Del total de especies, 86 presentaron rangos de profundidad menores a los $100 \mathrm{~m}$ y sólo 12 especies superaron los $200 \mathrm{~m}$. Sólo una especie tuvo un registro superior a los $150 \mathrm{~m}$ de profundidad en el Canal Beagle, mientras que 15 superaron dicha profundidad en el Estrecho de Magallanes. En el Canal Beagle y el Estrecho de Magallanes se registró el $57.5 \%$ de las especies, $71 \%$ de los géneros y $77.3 \%$ de las familias conocidas para la región magallánica.

Palabras clave: anfípodos, biodiversidad, Canal Beagle, Estrecho de Magallanes, región magallánica.

\section{REFERENCES}

Barnard, J.L. \& G.S. Karaman. 1991. The families and genera of marine gammaridean Amphipoda (except marine gammaroids). Part 1 \& 2. Rec. Aust. Mus. Suppl. 13: 1-866.

Bastida, R., A. Roux \& D.E. Martinez. 1992. Benthic communities of the Argentine continental shelf. Oceanol. Acta 15: 687-698.
Brambati, A., G. Fontolan \& U. Simeon. 1991. Recent sediments and sedimentological processes in the Strait of Magellan. Boll. Oceanol. Teor. Appl. 9: 217-259.

Brandt, A., K. Linse \& U. Weber. 1997. Abundance and diversity of peracarid taxa (Crustacea: Malacostraca) along a transect through the Beagle Channel. Polar Biol. 18: 83-90.

Cheetham, A.H. \& J.E. Hazel. 1969. Binary (presenceabsence) similarity coefficient. J. Paleontol. 5: 11301136.

Chiesa, I.L., G.M. Alonso \& D.G. Zelaya. 2005. Species richness and faunistic affinities of the Gammaridea and Corophiidea (Amphipoda) from shallow waters of southern Tierra del Fuego, Argentina: preliminary results. Sci. Mar. 69: 167-174.

Colizza, E. 1991. Preliminary report on coastal morphology and sea-bottom sediments of the Canales Beagle, Ballenero, Brecknock, Cockburn and Magdalena. Boll. Oceanol. Teor. Appl. 9: 273-279.

De Broyer, C. \& K. Jażdżewski. 1993. Contribution to the marine biodiversity inventory. A checklist of the Amphipoda (Crustacea) of the Southern Ocean. Doc. Trav. Inst. Roy. Sci. Nat. Belg. 73: 1-154.

De Broyer, C. \& M. Rauschert. 1999. Faunal diversity of the benthic amphipods (Crustacea) of the Magellan region as compared to the Antarctic (preliminary results). Sci. Mar. 63: 281-293.

Gambi, M.C. \& S. Mariani. 1999. Polychaetes of the soft bottoms of the Straits of Magellan collected during the Italian oceanographic cruise in February-March 1991. Sci. Mar. 63: 233-242.

Gonzalez, E. 1991. Actual state of gammaridean Amphipoda taxonomy and catalogue of species from Chile. Hydrobiologia 223: 47-68.

Hamamé, M. \& T. Antezana. 1999. Chlorophyll and zooplankton in microbasins along the Straits of the MagellanBeagle Channel passage. Sci. Mar. 63: 35-42.

Iturraspe, R., G. Bujalesky \& A. Coronato. 1989. Hidrología y variables climáticas del territorio de Tierra del Fuego. Información básica. CADIC Contr. Cient. 7: 1-196.

Knox, G.A. 1994. The Biology of the Southern Ocean (Studies in Polar Research). Cambridge University, Cambridge, England. 444 p. 
Lancellotti, D.A. \& J.A. Vásquez. 2000. Zoogeografía de macroinvertebrados bentónicos de la costa de Chile: contribución para la conservación marina. Rev. Chil. Hist. Nat. 73: 99-129.

Lowry, J.K. \& S. Bullock. 1976. Catalogue of the marine gammaridean Amphipoda of the Southern Ocean. Bull. Roy. Soc. New Zeal. 16: 1-187.

Myers, A.A. \& J. K. Lowry. 2003. A phylogeny and a new classification of the Corophiidea Leach, 1814 (Amphipoda). J. Crust. Biol. 23: 443-485.

Pagès, F. \& C. Orejas. 1999. Medusae, siphonophores and ctenophores of the Magellan region. Sci. Mar. 63: 51-57.
Panella, S., A. Michelato, R. Perdicaro, G. Magazzù, F. Decembrini \& P. Scarazzato. 1991. A preliminary contribution to understanding the hydrological characteristics of the Strait of Magellan: Austral Spring 1989. Boll. Oceanol. Teor. Appl. 9: 107-126.

Ríos, C., E. Mutschke \& E. Morrison. 2003. Biodiversidad bentónica sublitoral en el estrecho de Magallanes, Chile. Rev. Biol. Mar. Oceanogr. 38: 1-12.

Schellenberg, A. 1931. Gammariden und Caprelliden des Magellangebietes, Südgeorgiens und der Westantarktis. Furth. Zool. Res. Swed. Antarc. Exped. (1901-1903) 2: 1-290.

Stebbing, T.R.R. 1888. Report on the Amphipoda collected by H.M.S. Challenger during the years 1873-1876. Rep. Sci. Res. Voy. H.M.S. Challenger (1873-1876) 29: 1-1737. 